\title{
Colonisation by midges (Chironomidae, Diptera) of recently-created shallow ponds: implications for the restoration of lacustrine fringing wetlands
}

\author{
Brigitte Lods-Crozet ${ }^{1 *}$ and Emmanuel Castella ${ }^{2}$ \\ 1 Musée cantonal de Zoologie, Place de la Riponne 6, CP, 1014 Lausanne, Switzerland \\ 2 Laboratoire d'écologie et de biologie aquatique, University of Geneva, Geneva, Switzerland
}

Received 3rd November 2008; Accepted 26 October 2009

\begin{abstract}
As part of a wetland conservation programme for the Southern shore of lake Neuchatel (Western Switzerland), an experiment was started in 1993 to slow down the terrestrialization of the wetland. Sediments were removed in a reed-belt adjacent to an existing pond, at three different depths $(0.20,0.30$ and $0.40 \mathrm{~m})$, thus creating a new shallow pond. The colonisation by aquatic vegetation and invertebrates was monitored during three years (1994-1996) to evaluate the effect of the creation of a new pond on the chironomid diversity and abundance through time. Chironomids (78 taxa) were among the most diverse group colonising this fringing wetland. Significant differences in abundance were found between the reed-belt and the pond habitats (existing and recently created ponds). As expected, the latter was more productive, especially during the first two years of colonization. However, the chironomid diversity in the newly created pond, measured by the rarefied richness, was intermediate between the reed-belt (low diversity) and the pre-existing pond. Ordination of the sites on the basis of their chironomid assemblages confirmed this trend. The depth at which the sediment was scrapped off, had no major influence upon the chironomid assemblages. Finally, within the three years after creation of open water habitats, the production of chironomids and consequently their availability for dabbling ducks and wetland birds, were enhanced. However, this time was not enough for the chironomid community to reach the diversity of the pre-existing pond, to which it is connected. The creation of shallow ponds seemed to be crucial to slow down terrestrialization processes in this lacustrine wetland and to have only slight effects on the chironomid communities.
\end{abstract}

Key words: Fringing wetland / pond / colonisation / wetland management / Switzerland

\section{Introduction}

Wetlands represent some of the most threaten ecosystems on the planet and pose some of the most contentious questions to both scientists and policy makers (Maltby et al., 2000). They occupy about $6 \%$ of the world's land surface (Maltby and Turner, 1983) and occur on all continents. Estimated wetland loss in Europe is large, as exemplified by France (67\%: 1900-1995), Germany (57\%: 1950-1985) and Italy (66\%: 1938-1984) (Maltby et al., 2000). In Switzerland, a considerable reduction in wetland area occurred during the last century and induced negative effects resulting from a reduction in aquatic connectivity and from water level regulation. Protection of these dynamic ecosystems requires a sound management for the conservation and/or enhancement of the unique

\footnotetext{
*Corresponding author: brigitte.lods@vd.ch
}

species assemblages associated with wetland habitats. Wetland management often incorporates mowing, burning or grazing to slow down vegetation encroachment, as well as the creation of open water habitats for biodiversity maintenance or productivity enhancement for fish and waterfowl (Rehfisch, 1994; Sanders, 2000). However, little information is available about the impact of such restoration measures upon different components of the aquatic biodiversity.

Wetland invertebrates are vital links between primary production and vertebrate consumers (Murkin and Wrubleski, 1988). Among them, midge flies (Chironomidae) belong to the most abundant aquatic insects in freshwaters marshes (Wrubleski, 1987), and are therefore very important food for fish and water birds (Murkin et al., 1982; Maher and Carpenter, 1984; Batzer et al., 1993). Their distribution and abundance are also accurate indicators of physical, chemical and nutrient conditions 
of wetland habitats (Johnson et al., 1995). Chironomids also belong to the first colonizers of newly created or rewetted wetlands (Layton and Voshell, 1991; Batzer and Wissinger, 1996; Wrubleski, 1999, 2005).

The study site, the largest fringing wetland of Switzerland (the "Grande-Cariçaie") suffers, as many other such wetlands, from terrestrialization through forest expansion on its land-ward side. Pilot projects were developed to control invasion by shrubs and to prevent the degradation of reed-belts. Maintenance operations as the creation of ponds were also used as a method to enhance open water habitats (Gander, 2003; Sager and Clerc, 2006).

The objective of this study was to evaluate the influence upon chironomid community structure (composition, diversity and abundance) of the creation of a new shallow pond in a fringing wetland. Community succession was monitored in three habitat types: the new shallow pond, an adjacent reed (Phragmites australis) bed and two pre-existing ponds, one of which was connected to the new one. In term, we sought to assess the efficiency of the "reed-belt scraping" method of sediment removal in mitigating terrestrialization of freshwater marshes and to determine its usefulness for wetland restoration.

\section{Site and methods}

\section{Study site}

The study was carried out in the "Grande-Cariçaie", the largest fringing wetland of Switzerland, located on the South-eastern shore of Lake Neuchâtel. This wetland was created as a consequence of the lowering of the lake water level during the "first correction of Jura waters" (1880) and now forms an almost continuous belt of $42.5 \mathrm{~km}$ length and $480 \mathrm{~m}$ average width. After the second correction of Jura's hydrological system (completed in the 1970's), mean annual water level fluctuations were reduced below $1 \mathrm{~m}$. Management programmes were set up in 1987 to prevent the drying up of the wetland, to restrain the advance of the forest, to ensure the survival of all types of fringing wetland species and to slow down the erosion of the lakeshore.

In January 1993, an experiment was started to slow down the terrestrialization of the wetland, by sediment removal in a reed-belt (Phragmites australis (Cavanilles) Steudel) adjacent to an older pond (pond B) created in 1988 ("Font" sector) (648'45"E, 46 50'30"N, altitude $430 \mathrm{~m}$ a. s. 1.) (Fig. 1). Reed-belt rhizomes and sediments were removed on a surface area of $5300 \mathrm{~m}^{2}$ and at three different depths $(0.20,0.30$ and $0.40 \mathrm{~m})$ in order to test the recolonisation rate of the reed-belt.

Mean annual air temperature is $10.0^{\circ} \mathrm{C}$, mean annual precipitation is $84 \mathrm{~mm}$ (data Swiss Forecasting Institute). Freezing of the open water areas did not exceed 10-20 days (January and February) during the sampling programme (1994-1996). Water physico-chemical parameters were monitored from January 1997 to June 1998
(Castella-Müller, 2004). Water was well mineralised (average electric conductivity: $468 \mathrm{mS} . \mathrm{cm}^{-1}$ ), average nitrates and total phosphorus concentrations $\left(\mathrm{NO}_{3}-\mathrm{N}\right.$ : $0.11 \mathrm{mg} . \mathrm{L}^{-1}$; Ptot: $0.03 \mathrm{mg} . \mathrm{L}^{-1}$ ) were low. The area was connected with the lake either by seepage through the littoral sandy dunes or through the adjacent pond that receives lake water at high water levels (Table 1).

\section{Sampling regime}

Twelve sampling stations were selected in three different habitats in order to monitor the colonisation by midges: (i) the untouched reed-belt (RB) (five stations representing different degrees of connection with the adjacent pond and covering a moisture gradient, $\mathrm{n}^{\circ} 2,3$, 5, 8 and 10); (ii) two older ponds created in 1988 (pond A (PA): station 1; pond $\mathrm{B}$ (PB): stations 11 and 12) considered as references; and (iii) the newly-created pond (NCP) (1993) (four stations, $\mathrm{n}^{\circ}$ 4, 6, 7 and 9, scraped at three different depths) (Table 1). The adult chironomid fauna was monitored during three years (1994-1996) monthly or bi-monthly from April to late August. Each month, adults were collected using two emergence traps per station $\left(1075 \mathrm{~cm}^{2}\right.$ each), left in place for five consecutive days.

After sorting, the male adult chironomids were stored in $70 \%$ ethanol and specimens were mounted on microscopic slides in a mixture of lactic acid, glycerol and polyvinylic alcohol (Reymond, 1994). Identification to species level was carried out when possible using Lehmann (1970), Pinder (1978), Lindeberg and Wiederholm (1979), Reiss and Säwedal (1981), Rossaro (1985), ContrerasLichtenberg (1986), Wiederholm (1989) and Saether (1995). The female chironomids were only counted.

\section{Data analyses}

Given the heterogeneity of abundances between samples, the taxonomic richness was calculated using the rarefaction procedure (Heck et al., 1975; Krebs, 1999). Rarefaction simulates random draws of a fixed number of individuals within the samples (or combined samples) to be compared. The number of individuals drawn is based upon the least abundant sample. Rarefied richness is not an estimate of the total community richness, but it allows an unbiased comparison between samples of unequal abundances. It can also be regarded as a diversity measure, because, for a given number of observed taxa in a sample, rarefied richness will increase with the evenness of the distribution of abundance between taxa. Calculations were performed with the function "rarefy" from the "vegan" library in the R software ( $\mathrm{R}$ Development Core Team, 2009). The function calculates the rarefied richness for a given number of individuals from the Hurlbert (1971) formula, together with a standard error following Heck et al. (1975). 


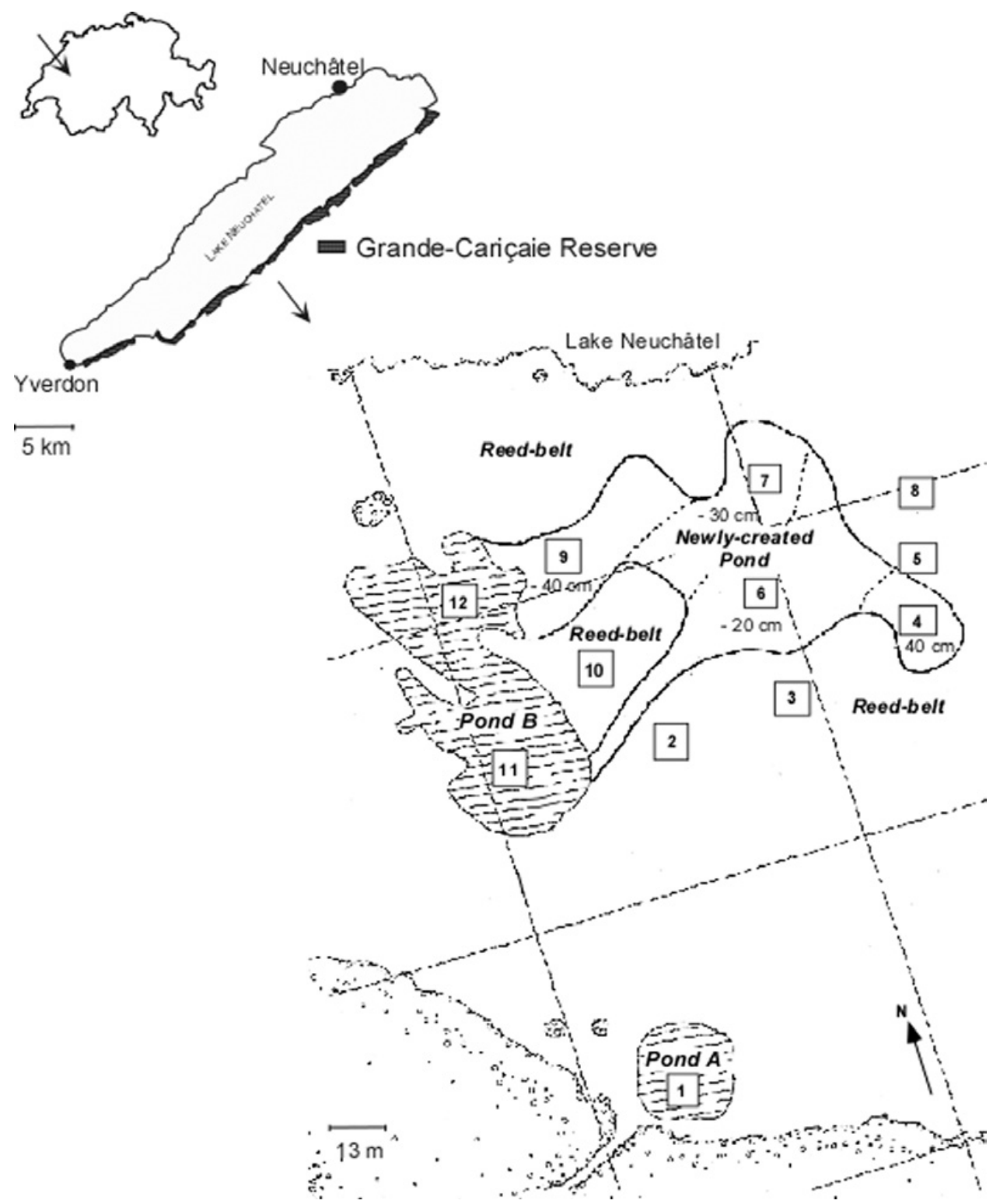

Fig. 1. Location of the sampling stations in the study area. The old ponds are A and B.

Table 1. General characteristics of the sampling stations and their dominant vegetation.

\begin{tabular}{|c|c|c|c|c|c|c|c|}
\hline Site & Station & $\mathrm{N}^{\circ}$ & $\begin{array}{c}\text { Date } \\
\text { of creation }\end{array}$ & $\begin{array}{l}\text { Depth } \\
(\mathrm{m})\end{array}$ & $\begin{array}{l}\text { Surface } \\
\text { area }\left(\mathrm{m}^{2}\right)\end{array}$ & $\begin{array}{l}\text { Dominant } \\
\text { vegetation }\end{array}$ & Remarks \\
\hline$\overline{1}$ & Reed-belt (RB) & 10,2 & ca. 1880 & $0.00-0.20$ & / & $\begin{array}{l}\text { Phragmites } \\
\text { australis }\end{array}$ & $\begin{array}{l}\text { Connected with the pond B } \\
\text { from March to May }\end{array}$ \\
\hline 1 & Reed-belt (RB) & $3,5,8$ & ca. 1880 & $0.00-0.20$ & / & $\begin{array}{l}\text { Phragmites } \\
\text { australis }\end{array}$ & $\begin{array}{l}\text { Permanently connected } \\
\text { with pond } \mathrm{B}\end{array}$ \\
\hline 2 & Newly-created pond (NCP) & 6 & 1993 & 0.2 & 5300 & $\begin{array}{l}\text { Myriophyllum } \\
\text { spicatum }\end{array}$ & $\begin{array}{l}\text { Permanently connected } \\
\text { with pond } \mathrm{B}\end{array}$ \\
\hline 2 & Newly-created pond (NCP) & 7 & 1993 & 0.3 & / & Typha latifolia & $\begin{array}{l}\text { Permanently connected } \\
\text { with pond } \mathrm{B}\end{array}$ \\
\hline 2 & Newly-created pond (NCP) & 4 & 1993 & 0.4 & / & No vegetation & $\begin{array}{l}\text { Permanently connected } \\
\text { with pond } \mathrm{B}\end{array}$ \\
\hline 2 & Newly-created pond (NCP) & 9 & 1993 & 0.4 & / & $\begin{array}{l}\text { Myriophyllum } \\
\text { spicatum }\end{array}$ & $\begin{array}{l}\text { Permanently connected } \\
\text { with pond } \mathrm{B}\end{array}$ \\
\hline 3 & Pond B (PB) & 11,12 & 1988 & $1.00-1.50$ & 3100 & $\begin{array}{l}\text { Myriophyllum } \\
\text { spicatum }\end{array}$ & Connected with the lake \\
\hline 4 & Pond A (PA) & 1 & 1988 & $0.10-0.40$ & 730 & Chara hispida & $\begin{array}{l}\text { Connected with the lake } \\
\text { during floods }\end{array}$ \\
\hline
\end{tabular}


Table 2: Comparison of chironomid densities between sites and years. Results of the Mann-Whitney U test (significant results are shown in bold, $p<0.05$ ). For abbreviations of sites, see Table 1

\begin{tabular}{lccc}
\hline Sites/Year & 1994 & 1995 & 1996 \\
\hline $1-2$ & $\mathbf{0 . 0 0 0}$ & $\mathbf{0 . 0 0 2}$ & 0.205 \\
$1-3$ & $\mathbf{0 . 0 0 3}$ & $\mathbf{0 . 0 0 1}$ & 0.050 \\
$1-4$ & $\mathbf{0 . 0 2 3}$ & $\mathbf{0 . 0 3 6}$ & 0.169 \\
$2-3$ & 0.348 & 0.502 & 0.422 \\
$2-4$ & 0.454 & 0.621 & 0.336 \\
$3-4$ & 0.149 & 0.679 & 0.768 \\
\hline
\end{tabular}

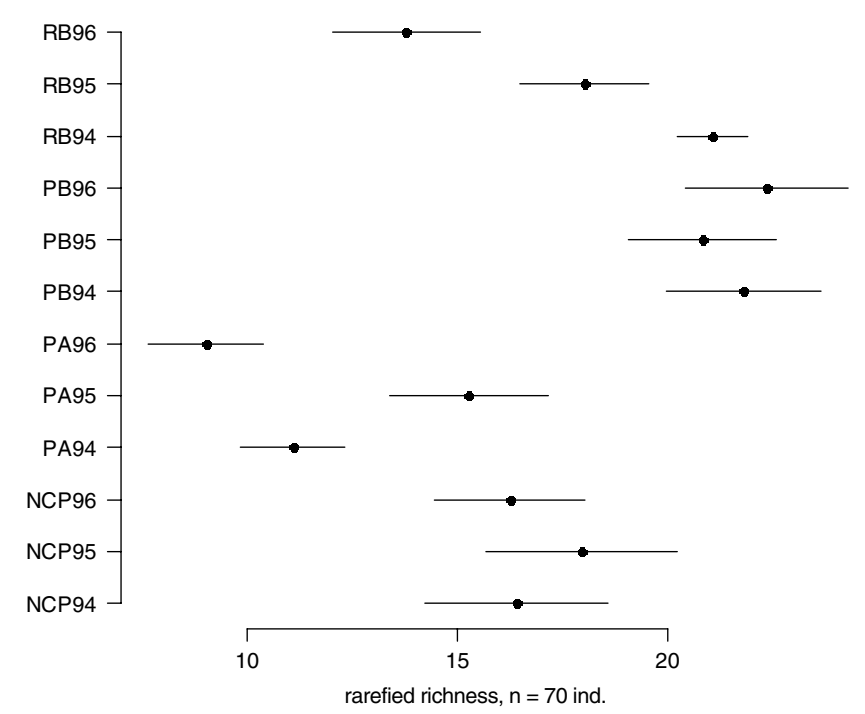

Fig. 2. Rarefied richness (average number of chironomid taxa for 70 individuals $\pm 1 \mathrm{SE}$ ), calculated for the four sites at each of the three years.

Mann-Whitney U-test was used to examine whether there were significant differences concerning number of taxa and density between habitats and depths. Correspondence analysis (CA), associated with betweenclass correspondence analyses (Dolédec and Chessel, 1987, 1989; Thioulouse et al., 1997) were used to ordinate the samples in terms of taxonomic composition and to describe and quantify the differences between sites and dates. All multivariate analyses were carried out using the ade4 library (Chessel et al., 2004) for the R software (R Development Core Team, 2009).

\section{Results}

\section{Taxonomic composition, diversity and abundance}

During the study period, about 7000 adult chironomids were caught, in which female made up 55 to $82 \%$ in the reed-belt (RB), but only 38 to $56 \%$ in the ponds. Seventyeight taxa (59 identified to species level belonging to 34 genera) were identified: 10 Tanypodinae (9 genera), 16 Orthocladiinae (8 genera), 43 Chironomini (14 genera) and 9 Tanytarsini (4 genera) (Table 2). The rarefied

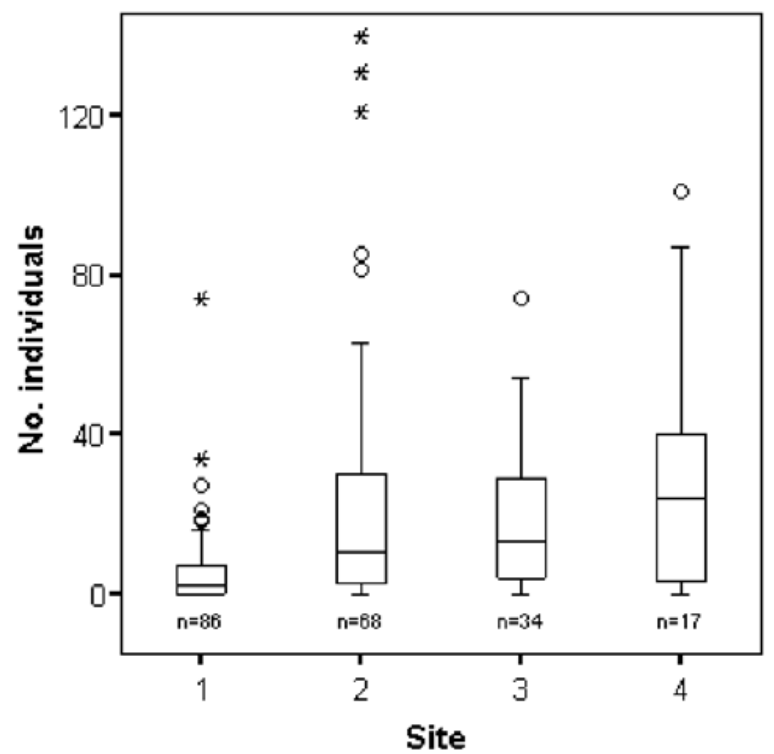

Fig. 3. Box-whisker graphs showing the distribution of chironomid abundance (individuals $/ 0.2 \mathrm{~m}^{2}$ ) in the four sites (1, reed-belt; 2 , new-created pond; 3 , pond $\mathrm{B} ; 4$, pond A) during April-late August 1994 to 1996; $n$ : numbers of stations $\times$ dates. The box indicates the interquartile range (Q25-Q75) and contains the median (horizontal line).

richness (expressed as the average number of taxa for 400 individuals, all dates combined) had the highest value in pond $\mathrm{B}(\mathrm{PB})(44.1 \pm 1.8)$, followed by the reed-belt $(41.1 \pm 0.9)$ and the newly created pond (NCP) $(39.6 \pm 2.4)$. Pond A (PA) had the lowest richness $(29.9 \pm 1.5)$. The differences were significant except between RB and NCP where the confidence limits around the mean overlapped.

When the dates were considered separately (Fig. 2), significant differences in chironomid diversity were measured between years only in pond $\mathrm{A}$ and in the reed-belt. This latter fact could be in relation with the greater variability of the water level during the three years sampling. There was no significant changes over the years in pond $\mathrm{B}$ and in the newly created pond.

Only six species had a relative abundance above $5 \%$ of the total number of individuals: Tanypus punctipennis (12.4\%), Xenopelopia nigricans (5.2\%) (Tanypodinae), Cricotopus sylvestris (6.1\%), C. intersectus (5.0\%) (Orthocladiinae), Tanytarsus excavatus $(9.2 \%)$ and $T$. mendax $(7.2 \%)$ (Chironominae-Tanytarsini). Species of the Chironominae-Chironomini contributed less than 3\%. Endochironomus dispar and Polypedilum sordens dominated, followed by Chironomus pallidivittatus and Parachironomus parilis.

Overall, the mean density of chironomids emerging from the pond habitats (the pre-existing ponds (PA, PB) and the newly-created one (NCP)) was always higher (64.9-163.4 individuals. $\mathrm{m}^{-2}$ ) than from the reed-belt (9.943.5 individuals. $^{-2}$ ) (Mann-Whitney $U$-test, $p<0.001$ ) (Fig. 3). However, the temporal trend showed that the chironomid density was significantly higher in the three pond sites than in the reed-belt during the two first years. 


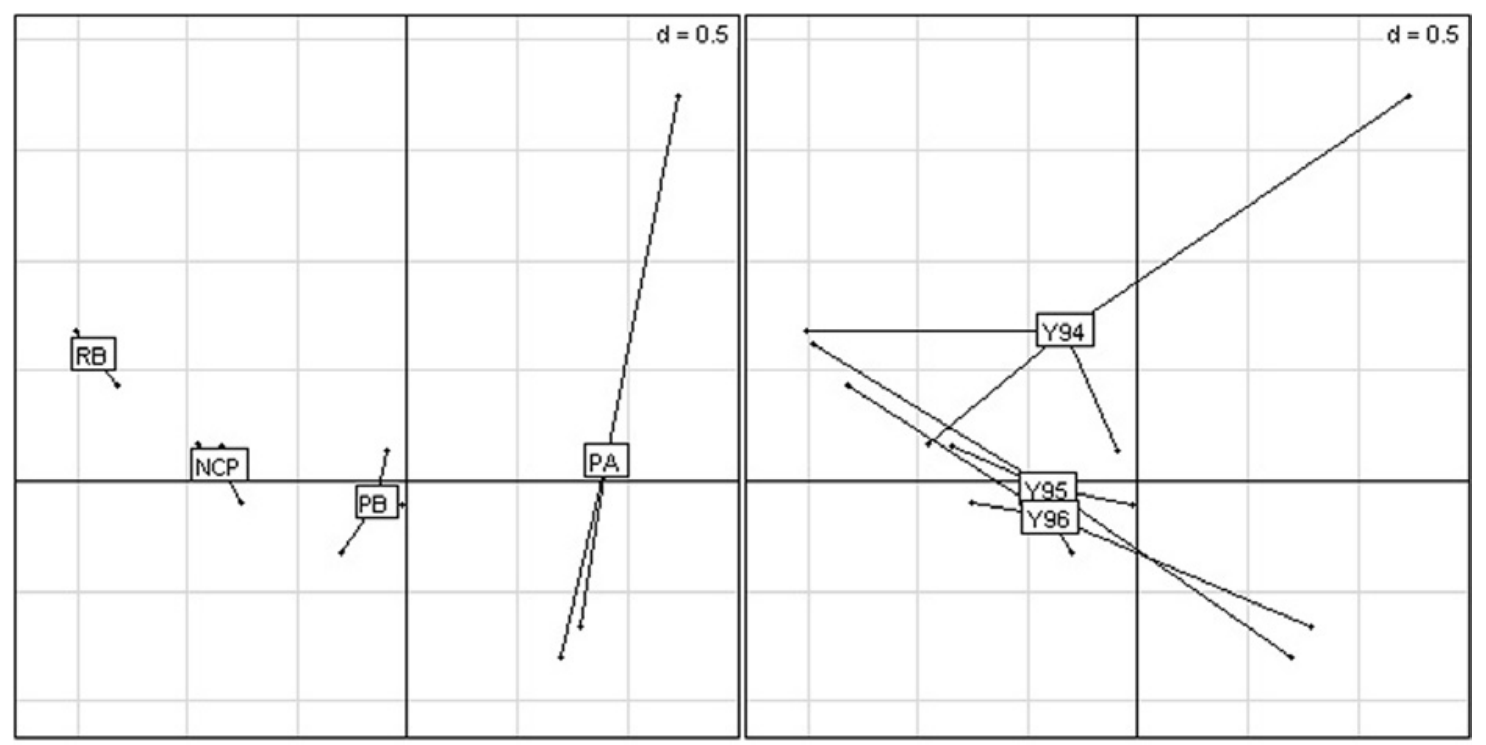

Fig. 4. Ordination of the 12 site *years by correspondence analysis (first factorial plane, horizontal axis $=21 \%$ of variability, vertical axis $=17 \%$ ). Left: site $*$ years grouped according to the four sites, right: site $*$ years grouped according to the three years.

In 1996, the difference was only slightly significant between the reed-belt and pond B. This could be related to low densities in the three ponds during the third year of study (Table 2).

\section{Ordination of the four sites on the basis of their chironomid assemblages over time}

The ordination of the 4 sites $* 3$ years by a correspondence analysis (Fig. 4) showed a clear separation of the sites along the F1 axis. The between-site variability accounted for $42 \%$ of the total faunal variability and was significant (permutation test, $p=0.001$ ). The chironomid composition in NCP was intermediate between RB and the adjacent $\mathrm{PB}$, even after three years. The between-year effect accounted for $18 \%$ of the faunal variability and was not significant $(p=0.71)$. The highest between-year variability was observed in the small pond A.

The faunal data table was reorganized according to the first axis scores of the ordination (Table 3). It revealed contrasted trends in the six dominant species. Tanypus punctipennis was present in all sites but with higher densities in NCP; its decreased with time after sediment removal suggesting its pioneer character. An increase in density through years was evident for Cricotopus intersectus, C. sylvestris and Tanytarsus mendax. They could be considered as secondary colonisers of the new open water habitat. Tanytarsus excavatus was a characteristic species of the permanent pond, associated with submerged vegetation and it occurred in large numbers in pond $\mathrm{A}$. Xenopelopia nigricans was localized almost exclusively in the flooded reed-belt (stations 5 and 8) together with Zavrelimyia sp. (station 3) at a lower abundance and Microtendipes diffinis in July in stations 2 and 10 when the reed-belt had drying up. Most of these characteristic species were bi- or multivoltine except for Xenopelopia nigricans which was univoltine.

\section{Effect of the depth of sediment removal upon the community structure}

The depth of sediment removal $(20,30$ and $40 \mathrm{~cm})$ in the newly-created pond habitat had no major influence upon the chironomid abundances (Fig. 5). The chironomid density at these three depths was not significantly different (Mann-Whitney U-test, $p>0.05$ ) during the three years.

\section{Discussion}

Twelve species collected during the course of this study had never been recorded in Switzerland previously (see Table 3) (Heiri, 1996; Lods-Crozet, 1998; Otto and Schiegg, 1999). This quite large number highlights the lack of systematic studies of this family in Switzerland. Taxonomical uncertainty remained about a species close to Metriocnemus brusti because of the low number of collected specimens (Saether, pers. comm.). Most of the 78 taxa were already collected in adjacent countries, e.g. France (Serra-Tosio and Laville, 1991; Laville and SerraTosio, 1996), Austria (Janecek et al., 2002) and Germany (Samietz, 1996), but this work represents a first reference list of chironomid species in a fringing wetland for Switzerland.

Almost all the species collected in the reed-belt and the different ponds were relatively eurytopic. However, distinct preferences for shallow stagnant or slow-flowing habitats (e.g. pools, ponds, shallow lakes, littoral zones of lakes) are indicated for them in the literature (Reiss, 1968; Moller Pillot and Buskens, 1990). Tanypus punctipennis is 


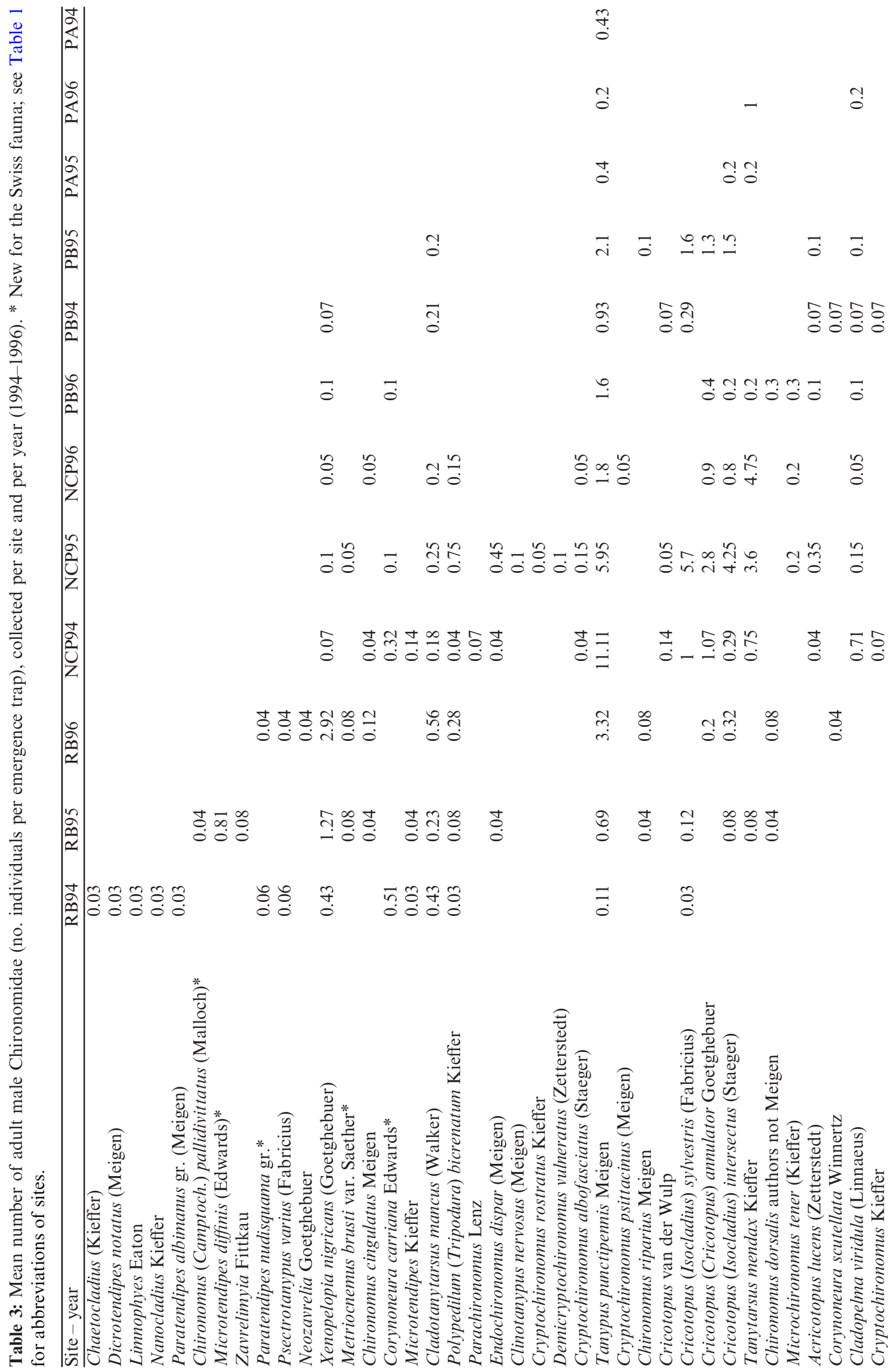




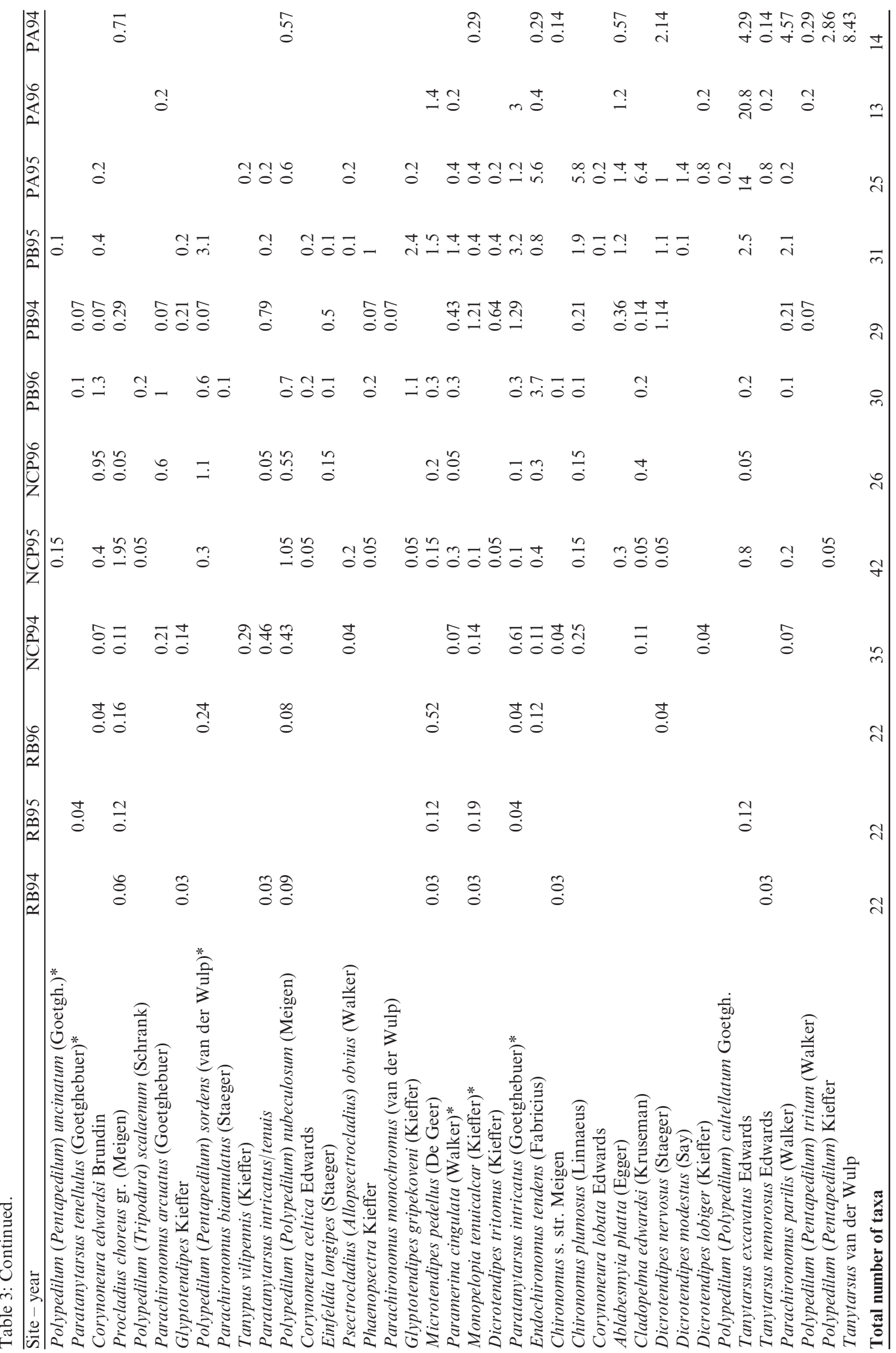




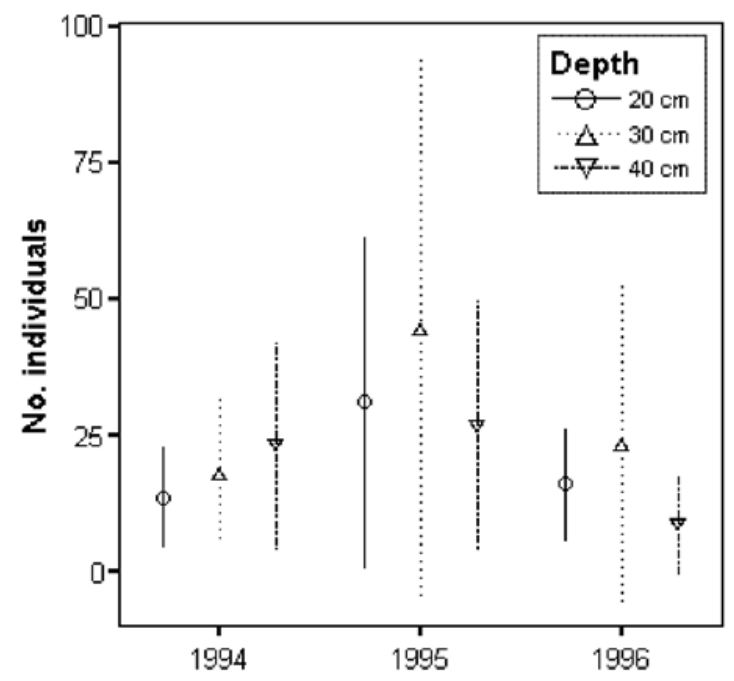

Fig. 5. Mean chironomid abundance (individuals $/ 0.2 \mathrm{~m}^{2} \pm \mathrm{SD}$ ) in the newly-created pond at three depths during three years.

characteristic of stagnant waters, eutrophic and hypertrophic habitats (Caspers and Heimbach, 1995). Cricotopus sylvestris is a ubiquitous species but often associated with plants (Mackey, 1979; Caspers and Heimbach, 1995). Xenopelopia nigricans was found as larvae in small stagnant waters and eutrophic lake littoral (Ferrarese, 1983; Wiederholm, 1989) but in this study the species colonised almost exclusively the reed-belt habitat (see Table 3). Several other taxa were found only in the reedbelt habitat which could be considered as a semi-terrestrial habitat (Psectrotanypus varius, Zavrelimyia, Chaetocladius, Limnophyes, Metriocnemus). Chironomid richness and abundance were lower in the reed-belt habitat, as observed by Wrubleski (1987) in marshes. On the other hand, Chironomus pallidivittatus had its highest abundance in the open water habitat (ponds), as in the open water areas of a North Dakota wetland studied by King and Wrubleski (1998).

The diversity of chironomids in this lake-fringe wetland (78 taxa) is not exceptional when compared to wetlands from other regions, but it is larger than usually reported for temporary ponds (Bazzanti et al., 1997; Leeper and Taylor, 1998). Wrubleski and Rosenberg (1990) collected 84 taxa of chironomids using emergence traps in a semiisolated wetland along the shore of Lake Manitoba, Canada. The same number of species was collected in peatlands in north-western Ontario by Rosenberg et al. (1988). As in our study, Stagliano et al. (1998) found 31 genera of chironomids emerging from a small wetland in the southeastern USA and Botts (1997) 34 genera of chironomid larvae in a Lake Erie coastal wetland.

Adult chironomids are good dispersers (Batzer and Wissinger, 1996) and are often the earliest colonists to arrive in newly created wetlands (Barnes, 1983; Layton and Voshell, 1991). Their life-history strategies allow them to rapidly colonize the early phases of newly inundated wetlands. However, the chironomid pool, from the adjacent lake littoral zone (about $40 \mathrm{~m}$ ) did not seem to play a very active role as reservoir for the colonisation of the wetland and the connected ponds. Only ubiquitous taxa like Procladius choreus gr., Cricotopus, Cryptochironomus, Demicryptochironomus vulneratus, Polypedilum nubeculosum gr. and Cladotanytarsus mancus gr. were common to both the adjacent lake and the studied ponds (Lods-Crozet, unpublished data).

Cricotopus species, well represented in the studied wetland, are recognized as pioneer in new habitats (Oliver, 1971; Titmus, 1979). The fact that the dominant species are bi- or multivoltine (Reiss, 1968; Lindegaard and Brodersen, 2000), emerging from early spring to mid-autumn, enhances the colonisation process by aerial dispersal of ovipositing adults. Feeding groups like collector-filterer larvae living on detritus and algae prevailed during the phase of colonisation (Maher and Carpenter, 1984). The earliest communities in the recent pond reflected this trend (Tanypus punctipennis, Cricotopus annulator, Chironomus pallidivittatus, Cladopelma edwar$d s i$, Paratanytarsus, Tanytarsus mendax). Furthermore, the desiccation resistance of both eggs and larvae (Delettre, 1990; Tokeshi, 1995) contributes to the rapid settlement of chironomid assemblages.

Several studies reported higher numbers of invertebrates in newly flooded marsh habitats than in adjacent older wetlands (Whitman, 1974; Danell and Sjöberg, 1982). In this study, the same trend was observed with a significantly lower abundance in the reed-belt habitat than in the newly created pond. However, the recently created pond had comparable densities with the older pond $\mathrm{B}$ during the three years of colonisation. In term of diversity, it seems that three years of colonisation was not sufficient to provide a the level of chironomid diversity that can be expected from the adjacent existing ponds, or even from the reed-belt that was subjected to water level fluctuations and seasonal drying out. The time effect was also not demonstrated, since the rarefied richness showed no significant differences between years. A similar result was established by Ruhi et al. (2009) in recently created ponds in Spain.

The experimental scraping of the reed-belt soil at three different depths had no major influence on the chironomid assemblages, but the zone scraped down to a depth of $20 \mathrm{~cm}$ was important as a breeding site for two rare species, the dragonfly Aeschna affinis and the mayfly Caenis lactea (Gander, 2003). It is also relevant to note that three bird species associated with the reed-belt and considered as key species in this wetland reserve, colonised the new created pond. This demonstrated that the sediment removal experiment has helped to restore the integrity and function of the reed-belt.

Because European wetlands are threatened and constantly reducing in extent, management strategies tend to promote their conservation and restoration. Whitman (1974) suggested that optimal conditions for invertebrate production in newly created wetlands occur during the first 1.5 to 4 years and he recommended drawdown between years 5 to 7 to improve food and cover for waterfowl. In the present study, the creation of a new 
shallow pond in the reed-belt of a lacustrine wetland was beneficial for chironomid abundance, but our results must be considered as preliminary because they are based only upon a three year period, which is not long enough to confirm chironomid diversification associated with the creation of the new open water habitats. Nevertheless, this management option could be considered as relevant because it slows down terrestrialization processes, compensates for wetland habitat destruction and the subsequent loss of species, enhances chironomid abundance and consequently their availability as food for dabbling ducks and shorebirds.

Acknowledgements. Antoine Gander from the team of the "Groupe de gestion de la Grande-Cariçaie" spent many hours in the field and in the laboratory collecting and processing samples. We thank Karine Richard for mounting chironomid specimens. Prof. Bruno Rossaro and Ole A. Saether confirmed some chironomid identifications. Funding and support was provided by the Groupe de gestion de la Grande-Cariçaie.

\section{References}

Barnes L.E., 1983. The colonization of ball-clay ponds by macroinvertebrates and macrophytes. Freshwat. Biol., 13, 561-578.

Batzer D.P. and Wissinger S.A., 1996. Ecology of insect communities in nontidal wetlandds. Ann. Rev. Ent., 41, 75100 .

Batzer D.P., McGee M., Resh V.H. and Smith R.R., 1993. Characteristics of invertebrates consumed by mallards and prey response to wetland flooding schedules. Wetlands, 13, 41-49.

Bazzanti M., Seminara M. and Baldoni S., 1997. Chironomids (Diptera: Chironomidae) from three temporary ponds of different wet phase duration in central Italy. J. Freshwat. Ecol., 12, 89-99.

Botts S., 1997. Spatial pattern, patch dynamics and successional change: chironomid assemblages in a Lake Erie coastal wetland. Freshwat. Biol., 37, 277-286.

Caspers N. and Heimbach F., 1995. The chironomids (Diptera, Nematocera) of an experimental pond system. In: Cranston P. (ed.), Chironomids: from genes to ecosystems, CSIRO Publishers, Melbourne, 273-279.

Castella-Müller J., 2004. Végétation aquatique et gradients environnementaux en zone alluviale péri-lacustre (lac de Neuchâtel, Suisse). Ph.D. Thesis, University of Geneva, Switzerland, $176 \mathrm{p}$.

Chessel D., Dufour A.B. and Thioulouse J., 2004. The ade4 package - I: One-table methods. $R$ News, 4, 5-10.

Contreras-Lichtenberg R., 1986. Revision der in der Westpaläarktis verbreiteten Arten des Genus Dicrotendipes Kieffer, 1913 (Diptera, Nematocera, Chironomidae). Ann. Naturhist. Mus. Wien, 88/89, 663-726.

Danell K. and Sjöberg K., 1982. Successional patterns of plants, invertebrates and ducks in a man-made lake. J. Appl. Ecol., 19, 395-409.

Delettre Y.R., 1990. Influence de la durée et de l'intensité de l'assèchement sur l'abondance et la phénologie des
Chironomides (Diptera) d'une mare semi-permanente peu profonde. Arch. Hydrobiol., 114, 383-399.

Dolédec S. and Chessel D., 1987. Rythmes saisonniers et composantes stationnelles en milieu aquatique. I: Description d'un plan d'observations complet par projection de variables. Acta Oecol., 8, 403-426.

Dolédec S. and Chessel D., 1989. Rythmes saisonniers et composantes stationnelles en milieu aquatique. II: Prise en compte et élimination d'effets dans un tableau faunistique. Acta Oecol., 8, 207-232.

Ferrarese U., 1983. Chironomidi. 3 (Diptera, Chironomidae: Tanypodinae), Guide per il riconoscimento delle specie animale delle acque interne italiane 26, Consiglio nazionale della ricerche, Verona, $67 \mathrm{p}$.

Gander A., 2003. Gestion des roselières par décapage - Bilan de l'essai pilote de Font (FR), Grande-Cariçaie, Groupe d'étude et de gestion, Yverdon-les-Bains, $30 \mathrm{p}$.

Heck K.L. Jr., van Belle G. and Simberloff D., 1975. Explicit calculation of the rarefaction diversity measurement and the determination of sufficient sample size. Ecology, 56, 14591461.

Heiri O., 1996. Die Frülingsemergenz der Zuckmücken (Diptera, Chironomidae) einer Restwasserstrecke der Engelberger Aa (OW/NW). Diplomarbeit, ETH-EAWAG, Kastanienbaum, $79 \mathrm{p}$.

Hurlbert S.H., 1971. The nonconcept of species diversity: a critique and alternative parameters. Ecol. Monogr., 54, 187211.

Janecek B., Contreras R. and Moog M., 2002. Arteninventar für osterreich-Diptera: Chironomidae (Zuckmücken). In: Moog O. (ed.), Fauna Aquatica Austriaca. Teil III, Wasserwirtschaftskataster, Bundesministerium für Land und Forstwirschaft, Wien, 1-23.

Johnson R.K., Wiederholm T. and Rosenberg D.M., 1995. Freshwater biomonitoring using individual organisms, populations, and species assemblages of benthic macroinvertebrates. In: Rosenberg D.M. and Resh V.H. (eds.), Freshwater biomonitoring and benthic macroinvertebrates, Chapman \& Hall, New York, 40-158.

King R.S. and Wrubleski D.A., 1998. Spatial and diel availability of flying insects as potential duckling food in prairie wetlands. Wetlands, 18, 100-114.

Krebs C.J., 1999. Ecological methodology, Addison Wesley Longman, Inc., $620 \mathrm{p}$.

Laville H. and Serra-Tosio B., 1996. Additions et corrections à l'inventaire des Chironomidés (Diptera) de France depuis 1990. Ann. Limnol. - Int. J. Lim., 32, 115-121.

Layton R.J. and Voshell J.R., 1991. Colonization of new experimental ponds by benthic macroinvertebrates. Env. Ent., 20, 110-117.

Lehmann J., 1970. Revision der Europäischen Arten (männliche Imagines) der Gattung Parachironomus Lenz (Diptera, Chironomidae). Hydrobiologia, 33, 129-158.

Leeper D.A. and Taylor B.E., 1998. Insect emergence from a South Carolina (USA) temporary wetland pond, with emphasis on the Chironomidae (Diptera). J. N. Amer. Benthol. Soc., 17, 54-72.

Lindeberg B. and Wiederholm T., 1979. Notes on the taxonomy of European species of Chironomus (Diptera: Chironomidae). Ent. Scand., 10, Suppl., 99-116.

Lindegaard C. and Brodersen K.P., 2000. The influence of temperature on emergence periods of Chironomidae 
(Diptera) from a shallow Danish lake. In: Hoffrichter O. (ed.), Late 20th Century Research on Chironomidae: an anthology from the 13th international Symposium on Chironomidae, Shaker Verlag, Aachen, 33-324.

Lods-Crozet B., 1998. Chironomidae. In: Merz B., Bächli G., Haenni J.P. and Gonseth Y. (eds.), Diptera - Check-list. Fauna Helvetica 1, Centre Suisse de Cartographie de la Faune (CSCF), Schweizerische Entomologische Gesellschaft (SEG), Neuchâtel, 92-101.

Mackey A.P., 1979. Trophic dependencies of some larval Chironomidae (Diptera) anf fish species in the River Thames. Hydrobiologia, 62, 241-247.

Maher M. and Carpenter S.M., 1984. Benthic studies of waterflowl breeding habitat in South-western New South Wales. II. Chironomid populations. Aust. J. Mar. Freshwat. Res., $35,97-110$.

Maltby E. and Turner R.E., 1983. Wetlands are not wastelands. Geographical Magazine, 55, 92-97.

Maltby E., Blackwell M.S.A. and Baker C.J., 2000. Linking wetland science to policy: meeting challenge with special reference to water quality issues. In: Balazs E., Galante E., Lynch J.M., Schepers J.S., Toutant J.P., Werner D. and Werry P.A. (eds.), Biological resource management, connecting science and policy, Springer-Verlag, Berlin, 291-308.

Moller Pillot H.K.M. and Buskens R.F.M., 1990. [The larvae of the Netherlands Chironomidae (Diptera). Part C: Autoecology and distribution]. Nederlandse Faunistische mededelingen, $1 C, 1-85$.

Murkin H.R. and Wrubleski D.A., 1988. Aquatic invertebrates of freshwater wetlands: function and ecology. In: Hook D.D., McKee W.H. and Shear T.H. (eds.), The ecology and management of wetlands, Croom Helm, London, 239-249.

Murkin H.R., Kaminski R.M. and Titman R.D., 1982. Responses of dabbling ducks and aquatic invertebrates to an experimentally manipulated cattail marsh. Can. J. Zool., 60, 2324-2332.

Oliver D.R., 1971. Life history of the Chironomidae. Ann. Rev. Ent., 16, 211-230.

Otto C.J. and Schiegg K., 1999. Chironomidae (Diptera) of the forest reserve Sihlwald $\mathrm{ZH}$, with 21 new records for Switzerland. Mitteilungen der Schweizerischen Entomologischen Gesellschaft, 72, 95-103.

Pinder L.C.V., 1978. A key to adult males of British Chironomidae (Diptera). Freshwater Biological Association Scientific Publication n 37, 168 p.

R Development Core Team, 2009. R: A language and environment for statistical computing. R Foundation for Statistical Computing, Vienna, ISBN: 3-900051-07-0, http://www. R-project.org.

Rehfisch M.M., 1994. Man-made lagoons and how their attractiveness to waders might be increased by manipulating the biomass of an insect benthos. J. Appl. Ecol., 31, 383-401.

Reiss F., 1968. Ökologische und systematische Untersuchungen an Chironomiden (Diptera) des Bodensees. Arch. Hydrobiol., 64, 176-323.

Reiss F. and Säwedal L., 1981. Keys to males and pupae of the Palaearctic (excl. Japan) Paratanytarsus Thienemann \& Bause, 1913, n. comb., with descriptions of three new species (Diptera: Chironomidae). Ent. Scand., 15, Suppl., 73-104.

Reymond O., 1994. Préparations microscopiques permanentes d'oligochètes : une méthode simple. Bull. Soc. Vaud. Sc. Nat., $83,1-3$.
Rosenberg D.M., Wiens A.P. and Bilyj B., 1988. Chironomidae (Diptera) of peatlands in northwestern Ontario, Canada. Holarctic Ecol., 11, 19-31.

Rossaro B., 1985. Revision of the genus Polypedilum Kieffer, 1912. I. Key to adults, pupae and larvae of the species known to occur in Italy. Mem. Soc. Ent. Ital., 62/63, 3-23.

Ruhi A., Boix D., Sala J., Gascon S. and Quintana X.D., 2009. Spatial and temporal patterns of pioneer macrofauna in recently created ponds: taxonomic and functional approaches. Hydrobiologia, 634, 137-151.

Saether O.A., 1995. Metriocnemus van der Wulp: Seven new species, revision of species, and new records (Diptera: Chironomidae). Ann. Limnol., 31, 35-64.

Sager L. and Clerc P., 2006. Factors influencing the distribution of Hydrocharis morsus-ranae L. and Rumex hydrolapathum Huds. in a mowed low-lying marshland, Réserve de Cheyres, lac de Neuchâtel, Switzerland. Hydrobiologia, 570, 223-229.

Samietz R., 1996. Kommentiertes Verzeichnis der auf dem Gebiet der Bundesrepublik Deutschland nachgewiesenen Chironomiden-Arten (Insecta; Diptera). Abh. Ber. Mus. Nat. Gotha, 19, 36-70.

Sanders M.D., 2000. Enhancing food supplies for waders: inconsistent effects of substratum manipulations on aquatic invertebrate biomass. J. Appl. Ecol., 37, 66-76.

Serra-Tosio B. and Laville H., 1991. Liste annotée des Diptères Chironomidés de France continentale et de Corse. Ann. Limnol., 27, 37-74.

Stagliano D.M., Benke A.C. and Anderson D.H., 1998. Emergence of aquatic insects from 2 habitats in a small wetland of the southeastern USA: temporal patterns of numbers and biomass. J. N. Amer. Benthol. Soc., 17, 37-53.

Thioulouse J., Chessel D., Dolédec S. and Olivier J.M., 1997. ADE-4: a multivariate analysis and graphical display software. Stat. Comput., 7, 75-83.

Titmus G., 1979. The emergence of midges (Diptera: Chironomidae) from wet gravel-pit. Freshwat. Biol., 9, 165-179.

Tokeshi M., 1995. Production ecology, In: Armitage P.D., Cranston P.S. and Pinder L.C.V. (eds.), The Chironomidae: Biology and ecology of non-biting midges, Chapman \& Hall, London, 269-296.

Whitman W.R., 1974. The response of macro-invertebrates to experimental marsh management. Ph.D. Dissertation, University of Maine, Orono.

Wiederholm T., 1989. Chironomidae of the Holarctic region. Keys and diagnoses. Part 3. Adult males. Ent. Scand., 34, 1-521.

Wrubleski D.A., 1987. Chironomidae (Diptera) of peatlands and marshes in Canada. Mem. Ent. Soc. Can., 140, 141-161.

Wrubleski D.A., 1999. Northern prairies marshes (Delta Marsh, Manitoba). II. Chironomidae (Diptera) responses to changing plant communities in newly flooded habitats. In: Batzer D.P., Rader R.B. and Wissinger S.A. (eds.), Invertebrates in Frehwater Wetlands of North America: Ecology and Management, New York: John Wiley \& Sons, Inc., 571-601.

Wrubleski D.A., 2005. Chironomidae (Diptera) responses to the experimental flooding of prairie marshes. Wetlands, 25, 200209.

Wrubleski D.A. and Rosenberg D.M., 1990. The Chironomidae (Diptera) of Bone Pile pond, delta-marsh, Manitoba, Canada. Wetlands, 10, 243-275. 